\title{
The use of multivariate analysis in the classification of Syrian governorates according to the number of communicable diseases 2001-2017 \\ Dr. Mohamed Akroush ${ }^{1}$, Dr. Fawaz Haidar ${ }^{2}$, Lama MInla ${ }^{3}$
}

\section{Summary:}

This study provides an assessment of the current status of communicable diseases in Syria Arab Public from 2011-2017. Within groups of the main diseases that the Syria Ministry of Health in cooperation with the World Health Organization are monitoring and following up on their numbers and whether the infection is verifiable and spreadable or is still suspected. This study provides a statistical map of the most areas that prone to communicable diseases in the Syrian governorates during years of study.

In this study we used the style of multivariate to analysis through the use of cluster and discriminatory to the classification of Syria governorates. The results show that there is no homogeneity in the number of infectious diseases among the Syria governorates, where the level of infection group within the average level by distinguishing these levels of communicable in the Syria governorates, a group of 21 diseases has showed different levels from the rest like Diphtheria diseases and leishmaniasis.

Keywords:

Communicable diseases, Syrian governorates, cluster analysis, discriminatory analysis.

\section{1-Introduction:}

Diseases of all kinds are one of the major problems of human beings at the individual, regional and global levels which lead to appear a group of problems in society that are affected by the geographical, economic and

\footnotetext{
${ }^{1}$ Department of Statistics and Programming, Faculty of Economics, Tishreen University, Syria.

${ }^{2}$ Department of Public Health, Faculty of Medicine, Tishreen University, Syria.

${ }^{3}$ Department of Statistics and Programming, Faculty of Economics, Tishreen University, Syria. e mail: lamaminla@tishreen.edu.sy

lamaminla19@gmail.com
} 
social environment [1]. The critical hypothesis of epidemiology is that duality of diseases and health don't occur randomly in the total population, but are more likely to be achieved in some members of population than others because of risk factors that may not randomly distributed between the population [2]. At the global and local levels, there is a constant and sustained follow up of the increasing incidence, control and recording of any recording of any new cases through surveillance programs (routine or sentinel), and the need to report any new numbers that many approach the criteria that are considered as indicators of risk which requiring rapid intervention. In the new International Regulations adopted by $58^{\text {th }}$ World Health Assembly in May 2005, a legal farm work designed to prevent, protect, combat and provide an effective and genuine response against diseases and health events that may constitute public health emergencies of international concern was developed to achieve that, the new International Health Regulations have put a set of rules and procedures to support the current global outbreak alert and response system, requiring counties to improve international surveillance and notification mechanism on public health events and to strengthen their national surveillance and intervention capacities [3]. To this end it is necessary to study several factors most important of which identify place and geographical areas which record the number of communicable diseases according to the type of diseases, the severity of its spread and the ways of spreading the infection, which gives the government and international supportive and active health authorities in change of controlling and treating communicable diseases the ability and dynamism to respond to any increase in the number of new infections and to treat and confirm confirmed infections which in turn become transmission and spread factors for the rest of population. Scientific literature relating to communicable diseases has extensive attention to all aspects of the incidence of infection direct monitoring of numbers (infected and suspected) location of outbreaks of specific communicable diseases and response to outbreaks. A critical evaluation of these literature reveals the most authors have been interested in the idea of spatial spread, with most studies focusing on the spread of communicable diseases 
according to geographical maps and predisposing factors in a geographical region. In 2019 Dalvi and Braga studied the spatial spread of Zika, Dengue and Chikungunya epidemic 2015-2019 in the municipality of Rio de Janerio, Brazil to study the infection rate of the population and determine the nearest neighbor through the hierarchy of distribution of viruses in the city according to the spatial distribution this gave the ability to study the propagation pattern of the three viruses [4]. In 2013 AlZiad and Hussein examined the spatial variability of communicable diseases in Sheikh Souk for the period 2004-2010 in the Republic of Iraq with the aim of demonstrating, analyzing and detecting the geographical distribution of communicable diseases and identifying the geographical environments in which the disease is concentrated or spread and the factors leading to this variation. The research showed that the incidence of smallpox was the first place, where the number of infections were 279 cases, 30.8\% of the total number of cases in 2004 with a turbulent increase in some communicable diseases such as typhoid 15\% of total infection in 2004 [5]. In 2016 Moore, Gelfeld, Okunogbe and Paul presented research to identify future areas most susceptible to diseases by designing an infectious disease vulnerability index, in order to provide an effective tool to help identify countries that may be more vulnerable to outbreaks. Infectious diseases promote awareness in them [6].

\section{2- Materials and methods:}

\subsection{Communicable diseases:}

Infectious diseases are a disease that can be transmitted or spread from one person or species to another either direct or indirect contact. The World Health Organization defines infectious diseases as diseases caused by pathogenic microorganisms such as: bacteria, viruses, parasites or fungi which can spread directly or indirectly from person to person [7]. Where an epidemic or outbreak can occur, when it meets several auxiliary aspects of the occurrence of the diseases of the worker (pathogen), population (hosts) and the environment thus constitute an ideal position for spread. Infectious agents are abundant, rapidly 
changing and can become resistant to drugs if they are not completely destroyed [8] [9]. Low vaccination rates, malnutrition, age (old and new) and immune depression all contribute to the risk of infection as overcrowding, poor regional design and hygiene due to poverty, dirty drinking water, rapid climate change and natural diseases can lead to conditions that allow easy transmission of disease [8], It may spread and movement of people or goods geographically can sometimes be more complex than a simple wave or simple graphical deployment model would describe. This is because the way these things are transferred is no longer confined to a local geography or a limited network of contacts, for example: an infectious flu spreading somewhere may become a complex deployment if virus carries are dispersed across highway networks to remote locations. Such influenza may spread beyond the region and even become international, consequently studies that focus on spatial diffusion should become more sophisticated and specialized than traditional methods of studying the composition of the affected population through a single-shape diffusion curve or other relater methods [9].

Communicable diseases are still forming a risk of health which are a main cause of death in many parts of the world. Tuberculosis is one of the top ten cause of death worldwide with an annual burden of 1.7 million dollars. In 2016 global deaths from other infectious diseases included 1.34 million hepatitis deaths, 1.0 million HIV related causes and about half a million malarias. Outbreak of vaccine-preventable diseases such as polio, rubella and other life threatening diseases pose a significant threat to different communities around the world [7]. Once an emergency is confirmed, there must be a rapid and comprehensive response to the control of infectious diseases. A specialized health camp should be established and the diseases should be managed quickly. The total objectives are rapid assessment, prevention, surveillance, diseases outbreak control and diseases management, for more detailed information on the logistics of infectious disease control [8]. 


\subsection{Classification of communicable diseases:}

Infectious diseases are major causes of death, disability, and social and economic

disruption for millions of people. In addition, they can be possibly transmitted via several

ways through pathogens, vectors, non-biological physical vehicles (water, soil, etc.), nonhuman reservoirs and human host [10]

Communicable diseases are classified into three categories: diseases that cause high levels of mortality, diseases that place a heavy burden on population, and diseases that can have serious global implications, given their spread and un predictable nature of the spread [11].

Therefore, infectious diseases can be classified into two categories based on mode of transmission:

- those that spread directly from person to person (through direct contact or exposure to the drop).

- those that spread indirectly through an interfering vector (mosquito or tick) or non-biological physical compound (soil and water) [12]

The existence of an environment that fosters the spread of infection among the population makes it difficult to combat and identify places and geographical regions is difficult for all government agencies and community bodies to address and reduce it.

\subsection{Global variation in dealing with communicable diseases:}

Throughout history diseases take a wide logical, geographical scope and communicable diseases are one of the most affected by the geographic structure and socio-economic environment of community, the impacts associated with these diseases are complementary in structure, alternating in intensity, strength and impact. While there are many preventive measures against the emergence and spread of communicable diseases may have disappeared especially in developed countries, but there are still communicable diseases characterized by 
high prevalence at a global level. One of the reasons is the increase in the population and the resistance of bacteria that cause the diseases due to the emergence of new chains which don't work with traditional treatments, in addition to the lock of medicines especially in countries where there are disorders that prevent the completion of the medical care model that leads cases and a decrease in the number of new infections. Due to the erratic planning of recourses in the world and the power of political decision-making in each country, economic and social differences are becoming increasingly contradictory. In regions with low levels of society and economic development in term of geographical distribution of communicable diseases, this group of countries is characterized by disorders associated with increasing population and food shortages, poor sanitation, poor health and presence of diseases that directly lead to death. This isn't the case in developed economic and social areas because of the advantages that members of society receive in socio-economic living conditions [1]. The World Health Organization established health regulation (IHR) (2005) which require that all countries have the capacity to detect, assess, report and respond to potential threats that is detection of potential threats through surveillance, laboratory and decision-making systems in health emergencies public and reporting specific diseases and any potential international health emergencies and responding to public health events [11]. Today's highly mobile, interdependent and interconnected world offers countless opportunities for the rapid spread of diseases. In particular, diseases that may turn into a pandemic that have made cholera, meningococcal diseases and yellow ever a very real and worrisome societal realm, making the urgent need for renewed surveillance efforts to prevent and control. Communicable diseases have aroused great international and new scientific challenges causing great human suffering and enormous economic damage [13]. It is important that all countries have the ability to detect and evaluate communicable diseases and respond to health events. Then they will be able to contain the spread of diseases within borders (foe each country without causing any an outbreak) thereby reducing the global spread of diseases [2]. This leads to the realization of the World Health Organization's vision of 
international public health, ie a safer world of communicable diseases, alert and ready to respond collectively to the threat of epidemics and other health emergencies that pose a serious threat to public health security. Through the formulation of a global alert and response system based on partnership, quality and transparency [13].

\subsection{Factors affecting the outbreak of communicable diseases:}

Increased number of infectious diseases types are directly or indirectly associated with a range of variables. Vulnerability refers to the ability of a state to limit the spread of outbreaks. The most affected countries have sufficient capacity to reduce, monitor and respond to the spread of diseases while the most resistant countries have the great capacity to do that while it may not be possible to prevent the first case(s) of a disease completely [6]. The maim four factors contributing to the spread of communicable diseases in any community were identified as follows:

- Demographic factors:

The spread of various infectious diseases, new and old increasing the impact of demographic, environmental, technological and other rapid changes in the human environment.

- Health factors:

Strong public health systems are in place to ensure the ability of a country to prevent, monitor and respond effectively to outbreaks of communicable diseases. They also reflect the ability of a government to deliver key healthy services such as vaccines and the proportion of people who benefit from clean water and improved health facilities to what extent communities can prevent [6].

- Economic factors:

It is known that the impact of infectious diseases is greater among the poorest segments due to many considerations which are the lack of food, medicine and the disorders in the communities [14].

- Political factors:

For local considerations of political factors that affecting the spread of communicable diseases, safety and strong funding are among the most indicators that make work within the health 
organization to provide primary health care and urgent and emergency health services that are needed in communicable diseases emergencies. In addition to domestic consideration, international political factors affect a country's ability to resist the spread of infectious diseases. Continued support from both bilateral donors and international organizations can help strengthening the health system of a country and provide the necessary funding, expertise and staff to prepare for respond to health crises [6].

Through the past few decades, The Eastern Mediterranean has been one of the regions of the world damaged deeply by war and political instability. The ongoing conflict and destruction have left the region plagued by countless health fears that have claimed many lives. War and chaos often provide the optimal conditions for the growth and re-emergence of infectious diseases [15].Once an emergency is confirmed, there must be a rapid and comprehensive response to the control of infectious diseases. A camp should have established (to prevent outbreaks, minimize casualties) and manage the disease quickly. The total objectives are rapid assessment, prevention, surveillance, disease control and disease management [8]. Many of the major determinants of health and the cause of infectious diseases fall outside the direct control of the health sector. Other sectors involved are those dealing with sanitation, water supply, environmental change, climate, education, agriculture, trade tourism, transport, industrial development and housing [11].

\subsection{The status of communicable diseases in Syria:}

The directorate of communicable diseases at the Syrian Ministry of Health has identified the communicable diseases groups according to World Health Organization announcements and successive updates through specific groups that are directly reported as soon as they are suspected (immediately reported). This is done through the Early warning and Rapid Response Program through a system set up in collaboration between the Syrian Ministry of Health and The World Health Organization 
which is a system for reporting a priority group of communicable and vaccine-related diseases. Achieving an effective response to the surveillance system is directly of priority diseases and surveillance of suspected cases based on standard definition [16], a part from direct war losses, the Syrian crisis that has engulfed since 2011 the country has caused many casualties due to preventable basic health care problems. Hospitals and ambulances were frequent targets for rockets and explosions which leading to the collapse of any previously existing health care infrastructure. More than 700 medical workers have been killed since the war began in 2011, and more than 60 health care facilities were distorted last year alone. Internally displaces to safe areas within the country from who moved to neighboring countries were forced to live in poor living conditions with limited access to basic sanitation and health care in the troubled areas of the country [15]. The epidemic threats and major faced by the displaced population after an emergency are the greatest challenge for any government facing similar circumstances as Syria has experienced in previous year. Resettlement in temporary location such as refugee camps may involve high population density, inadequate shelter, poor water and sanitation, this lack of basic health care poses an integrated threat of further infectious diseases among the population and a high risk of an epidemic [17]. In 2017 (74) cases of polio virus derived from type 2 vaccines were confirmed in the north-east of Syria (in Deir Ezzor, Raqqa and Homs) The first case was discovered on 3 March, while the last case was recorded in September 2017 [18].

\subsection{Statistical analysis:}

To study the spatial distribution of recorded infections from communicable diseases, the descriptive analytical method was applied using Spss25 by:

- Use cluster analysis (Hierarchical clustering Analysis) to get the results of a compilation of the 21 cases of communicable diseases approver by the Syrian Ministry of Health in accordance with the plans agreed upon the World Health Organization. The complete 
linkage method also called the farthest neighbor method was selected as one of the sequential cluster analysis methods in order to classify the Syria governorates in terms of the number of infectious diseases.

- The use of discriminatory analysis because it depends on the distinction between two or more group which are similar in many characteristics on the basis of several variables through the use of the distinctive function. This is achieved in the concept of dealing with the number of cases of communicable diseases in question which are similar in the origin of the diseases, methods of infection, and the way of spreading and responding to the outbreak in any society. But they differ in terms of the pathogen factor, the appropriate medications and some specific details of each particular infectious disease.

\section{Results and discussions:}

\section{1 cluster analysis of infectious diseases number:}

The directorate of communicable diseases data showed the number of infectious diseases reported in the year 2001-2017 for the purpose of classifying the Syrian governorates according to similar clusters of the number of suspected and confirmed infections from communicable diseases. Therefore, the governorates were classified based on data from the directorate of communicable diseases at the Syrian Ministry of Health as in the following table:

Table (1): The main groups (groups) for communicable diseases in the Syrian Ministry of Health.

\begin{tabular}{|c|c|c|c|c|c|}
\hline Group number & Details & $x_{i}$ & Group number & Details & $x_{i}$ \\
\hline 1 & Flaccid paralysis & $x_{1}$ & 12 & Mumps & $x_{12}$ \\
\hline 2 & Neonatal tetanus & $x_{2}$ & 13 & Tetanus electrophoresis & $x_{13}$ \\
\hline 3 & Meningitis & $x_{3}$ & 14 & Cutaneous leishmamiasis & $x_{14}$ \\
\hline 4 & Summer epidemic diarrhea & $x_{4}$ & 15 & Visceral leishmaniasis & $x_{15}$ \\
\hline 5 & Malaria & $x_{5}$ & 16 & Schistosomiasis & $x_{16}$ \\
\hline 6 & Tuberculosis & $x_{6}$ & 17 & Brucellosis & $x_{17}$ \\
\hline 7 & Measles & $x_{7}$ & 18 & Typhoid fever & $x_{18}$ \\
\hline 8 & Whooping cough & $x_{8}$ & 19 & Dog & $x_{19}$ \\
\hline 9 & Diphtheria & $x_{9}$ & 20 & Flu & $x_{20}$ \\
\hline 10 & Hepatitis & $x_{10}$ & 21 & Acute diarrhea & $x_{21}$ \\
\hline 11 & Rubella & $x_{11}$ & & & \\
\hline
\end{tabular}

Source: communicable diseases director, Syrian Ministry of Health 
The Syrian governorates are classified according to the data of the demographic survey conducted by the Central Bureau of statistics in Syria in 2017 according to the following table data:

Table (2): classification of Syrian Governorates

\begin{tabular}{|c|c|c|c|c|c|c|c|c|c|}
\hline Number & 1 & $\mathbf{2}$ & $\mathbf{3}$ & $\mathbf{4}$ & $\mathbf{5}$ & $\mathbf{6}$ & $\mathbf{7}$ & $\mathbf{8}$ & $\mathbf{9}$ \\
\hline $\begin{array}{c}\text { Governora } \\
\text { te }\end{array}$ & $\begin{array}{c}\text { Damasc } \\
\text { us }\end{array}$ & $\begin{array}{c}\text { Rif } \\
\text { Damasc } \\
\text { us }\end{array}$ & $\begin{array}{c}\text { Alepp } \\
\mathbf{0}\end{array}$ & $\begin{array}{c}\text { Lattaki } \\
\text { a }\end{array}$ & Tartous & $\begin{array}{c}\text { Idli } \\
\text { b }\end{array}$ & $\begin{array}{c}\text { Hom } \\
\text { s }\end{array}$ & $\begin{array}{c}\text { Ham } \\
\text { a }\end{array}$ & $\begin{array}{c}\text { Raqq } \\
\text { a }\end{array}$ \\
\hline Number & 10 & 11 & 12 & 13 & 14 & & & & \\
\hline $\begin{array}{c}\text { Governora } \\
\text { te }\end{array}$ & $\begin{array}{c}\text { Deir } \\
\text { Ezzor }\end{array}$ & Hasaka & Daraa & $\begin{array}{c}\text { Suway } \\
\text { da }\end{array}$ & $\begin{array}{c}\text { Quneitr } \\
\text { a }\end{array}$ & & & & \\
\hline
\end{tabular}

Source: Central Bureau of Statistic, Demographic Survey 2017

Data analysis by cluster analysis is an important method of data analysis for the purpose of grouping data on specific bases in order to arrive at an accurate description of multiple variables. What determines the type of relationship between the elements to be categorized are the variables or qualities they have. Therefore, it's necessary to know how to deal with all types of variables into clusters depending on how similar they are in a cluster in multiple forms. In this research, the hierarchical method is used where(n) vocabulary is sequentially clustered in (M) of clusters arranged in ascending order with $c_{1}$ being the weakest and $c_{m}$ the strongest [19]. Through the data of the two tables above, we'll apply the cluster analysis to the data of the number of the people infected with communicable diseases after the classification of the Syrian governorates, in order to find homogenous grouping among them, with the aim of simultaneous classification and comparison. The number of cases of communicable diseases in the Syrian governorates during the years of study, as shown in the following table: 
Table(3): Number of Infectious Diseases in the Syrian Governorates2001-2017

\begin{tabular}{|c|c|c|c|c|c|c|c|c|c|c|c|}
\hline $\begin{array}{l}\text { Diseases } \\
\text { Governorate }\end{array}$ & $x_{1}$ & $x_{2}$ & $x_{3}$ & $x_{4}$ & $x_{5}$ & $x_{6}$ & $x_{7}$ & $x_{8}$ & $x_{9}$ & $x_{10}$ & $x_{11}$ \\
\hline 1 & 211 & 0 & 830 & 0 & 0 & 9099 & 551 & 62 & 0 & 4385 & 103 \\
\hline 2 & 300 & 2 & 1308 & 0 & 0 & 3944 & 743 & 79 & 1 & 3662 & 124 \\
\hline 3 & 394 & 31 & 592 & 0 & 0 & 10535 & 1225 & 602 & 0 & 7677 & 47 \\
\hline 4 & 185 & 0 & 170 & 0 & 0 & 2010 & 234 & 118 & 0 & 6374 & 73 \\
\hline 5 & 126 & 1 & 251 & 0 & 0 & 1351 & 298 & 73 & 0 & 7167 & 99 \\
\hline 6 & 199 & 2 & 355 & 0 & 0 & 1605 & 347 & 213 & 0 & 2161 & 9 \\
\hline 7 & 299 & 8 & 474 & 0 & 0 & 2211 & 1097 & 209 & 0 & 7116 & 52 \\
\hline 8 & 273 & 5 & 520 & 0 & 0 & 2082 & 581 & 25 & 0 & 15798 & 127 \\
\hline 9 & 107 & 3 & 326 & 0 & 3 & 2037 & 452 & 373 & 0 & 3366 & 39 \\
\hline 10 & 277 & 5 & 374 & 0 & 0 & 1674 & 275 & 129 & 0 & 366 & 19 \\
\hline 11 & 155 & 34 & 187 & 0 & 76 & 2789 & 1567 & 909 & 0 & 2216 & 47 \\
\hline 12 & 132 & 1 & 431 & 0 & 0 & 594 & 395 & 145 & 0 & 892 & 21 \\
\hline 13 & 61 & 0 & 110 & 0 & 0 & 360 & 316 & 7 & 0 & 136 & 25 \\
\hline 14 & 40 & 0 & 37 & 0 & 0 & 293 & 168 & 51 & 0 & 456 & 30 \\
\hline Governorate & $\mathbf{x}_{12}$ & $\mathbf{x}_{13}$ & $\mathrm{x}_{14}$ & $\mathbf{x}_{15}$ & $\mathbf{x}_{16}$ & $x_{17}$ & $\mathbf{x}_{18}$ & $\mathbf{x}_{19}$ & $\mathbf{x}_{20}$ & $\mathbf{x}_{21}$ & \\
\hline 1 & 5236 & 0 & 12972 & 62 & 0 & 26836 & 881 & 2 & 32591 & 151472 & \\
\hline 2 & 8856 & 5 & 20830 & 0 & 0 & 32201 & 7880 & 6 & 801816 & 387924 & \\
\hline 3 & 5063 & 13 & 214398 & 45 & 0 & 32143 & 6456 & 8 & 68562 & 176134 & \\
\hline 4 & 1835 & 1 & 24915 & 91 & 0 & 1791 & 1564 & 0 & 432112 & 145076 & \\
\hline 5 & 2723 & 1 & 28187 & 47 & 0 & 2282 & 2419 & 2 & 256734 & 192767 & \\
\hline 6 & 1678 & 0 & 89266 & 125 & 0 & 7628 & 4279 & 5 & 32124 & 43741 & \\
\hline 7 & 3919 & 4 & 8497 & 14 & 0 & 14445 & 4219 & 10 & 293743 & 104400 & \\
\hline 8 & 3594 & 4 & 75967 & 13 & 5 & 33974 & 6079 & 6 & 128029 & 131821 & \\
\hline 9 & 1013 & 0 & 6385 & 1 & 22 & 40970 & 4030 & 1 & 75503 & 55204 & \\
\hline 10 & 549 & 0 & 16239 & 19 & 3 & 7124 & 540 & 5 & 37250 & 30728 & \\
\hline 11 & 3552 & 3 & 96415 & 0 & 0 & 42999 & 3660 & 4 & 134290 & 207504 & \\
\hline 12 & 2168 & 0 & 904 & 9 & 0 & 10646 & 5371 & 3 & 49951 & 41071 & \\
\hline 13 & 147 & 0 & 619 & 3 & 0 & 3551 & 350 & 1 & 39396 & 26185 & \\
\hline 14 & 1348 & 0 & 175 & 0 & 0 & 2301 & 419 & 1 & 63370 & 23663 & \\
\hline
\end{tabular}

Source: Researches calculations based on data from the directorate of communicable diseases in Syria during the study years.

Cluster analysis was used to find the relationship between the governorates based on similarity measures used, evident through the kinship matrix through which the similarity is determined or not between governorates, expressed based on the distanced derived between each province with the other governorates. The results of the cluster analysis will be presented in the following sequence by using the data of table (1) and (2) based on the data of table (3). The cluster analysis has been limited to the overall linkage method as shown in table below: 
Table (4): Agglomeration Schedule

Cluster Combined

\begin{tabular}{|r|r|r|r|r} 
Stage & Cluster 1 & Cluster 2 & Coefficients & Next Stage \\
\hline 1 & 7 & 14 & .031 & 2 \\
\hline 2 & 4 & 7 & .090 & 3 \\
\hline 3 & 2 & 4 & .293 & 9 \\
\hline 4 & 5 & 13 & .311 & 6 \\
\hline 5 & 8 & 10 & .530 & 8 \\
\hline 6 & 5 & 12 & .716 & 9 \\
\hline 7 & 3 & 6 & 1.327 & 13 \\
\hline 8 & 8 & 11 & 1.460 & 11 \\
\hline 9 & 2 & 5 & 1.959 & 10 \\
\hline 10 & 2 & 9 & 3.984 & 11 \\
\hline 11 & 2 & 8 & 5.923 & 12 \\
\hline 12 & 1 & 2 & 13.768 & 13 \\
\hline 13 & 1 & 3 & 18.650 & 0 \\
\hline \multicolumn{3}{|c|}{ Source: prepared by researchers using spss25 } \\
\hline
\end{tabular}

It is clear from the previous table that governorates of Homs and Quintieri were linked together as the distance between them $(0.31)$ is the smallest possible, which is measured in term of Euclidean square and the second step is the next stage from which Homs Governorate will be formed with the first step with Aleppo Governorate. The linking process continues to reach the rest of the groups where the largest distance was the last step which reached (18.650) where in this step was linked to the provinces of Damascus and Aleppo. The order of the governorates was represented by the shape of the tree represented by the following: 


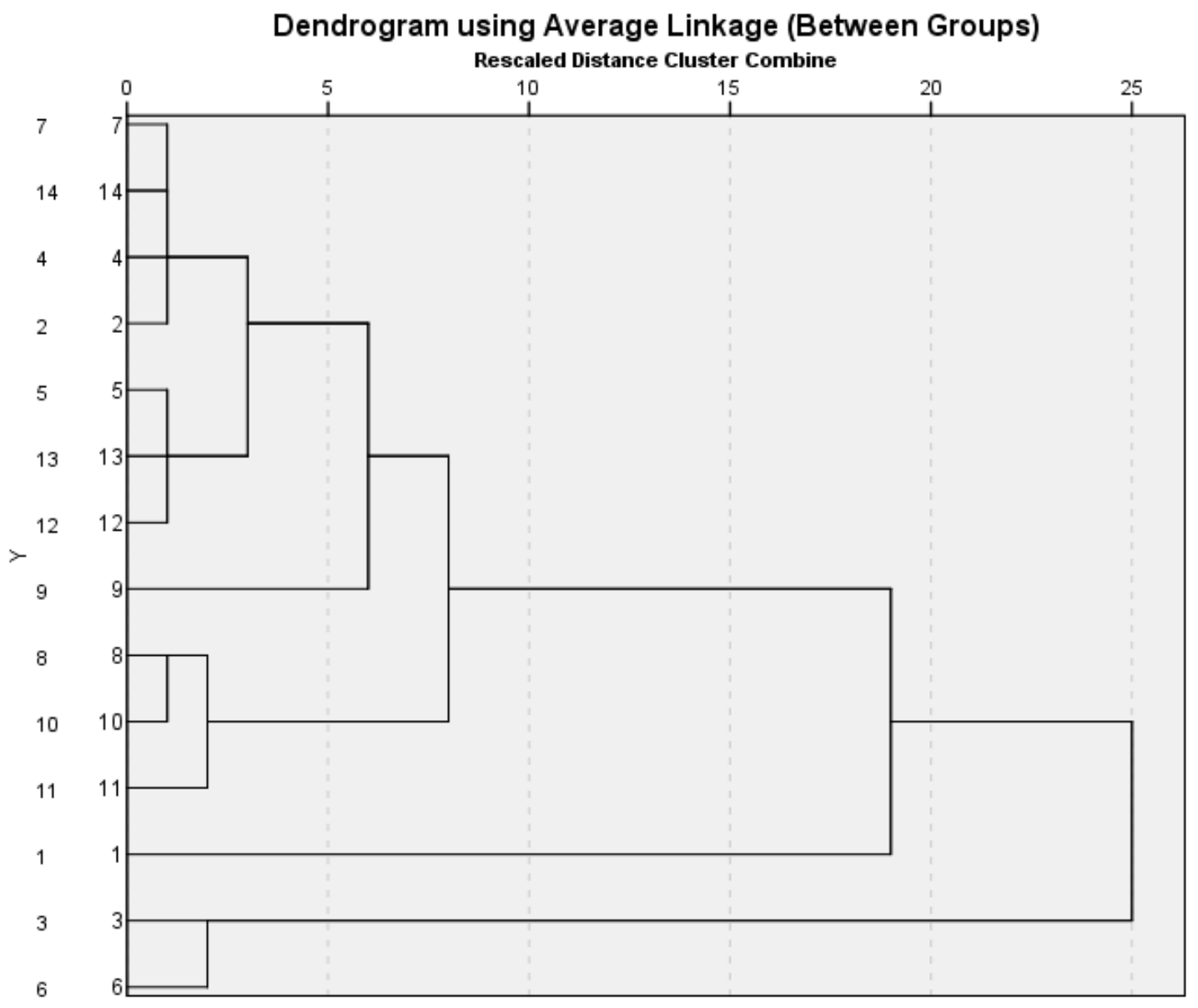

source: prepared by researchers using Spss25

It is clear from the previous figure that the number of clusters is 3 and the number of governorates in each cluster is shown as in the following table:

\begin{tabular}{|c|c|c|}
\hline \multicolumn{2}{|c|}{1} & 1 \\
\hline Cluster & 2 & 11 \\
\hline & & 2 \\
\hline & & 14.000 \\
\hline & & 0.000 \\
\hline
\end{tabular}

Source: prepared by researchers using Spss25

The result of the previous table indicates that the total classification of the Syrian governorates where one governorate was classified in the first cluster cases ( governorates with low incidence of communicable diseases ) which was Damascus Governorate , 11 cases in the second cluster ( governorates with moderate incidence of communicable 
diseases ) which were ( Rif Damascus, Lattakia, Tartous, Homs, Raqqa, Deir Ezzor, Hasaka, Daraa, Sweida and Quneitra) and two cases in the governorates of Aleppo and Idlib. This means that there is no homogeneity among the Syrian governorates in terms of the number of infectious diseases, thus accepting the first hypothesis.

\subsection{Study the assumptions necessary to apply discriminatory analysis:}

The method of discriminatory analysis relies on the separation of societies. Information on two or more communities is similar in character but quantitatively separate. Assuming that are $(\mathrm{m})$ random samples from communities of different size $\left(m_{1}, m_{2}, m_{3}, m_{4}, \ldots m_{n}\right)$

These categorizable data can be placed in a table in this figure [20]:

\begin{tabular}{|c|c|c|c|c|c|}
\hline Individual & $\mathrm{X}_{1}$ & $\mathrm{X}_{2}$ & $\ldots$ & $\mathrm{x}_{\mathrm{p}}$ & \multirow{7}{*}{ I } \\
\hline 1 & $\mathrm{X}_{111}$ & $\mathrm{X}_{112}$ & $\ldots$ & $\mathrm{X}_{11_{p}}$ & \\
\hline 2 & $\mathbf{X}_{211}$ & $\mathbf{X}_{212}$ & $\ldots$ & $\mathrm{X}_{21 \mathrm{p}}$ & \\
\hline . & $\cdot$ & $\cdot$ & . & . & \\
\hline . & $\cdot$ & $\cdot$ & . & . & \\
\hline . & . & . & . & . & \\
\hline $\mathbf{n}_{1}$ & $\mathrm{X}_{\mathrm{s111}}$ & $\mathbf{X}_{\text {sl112 }}$ & $\ldots$ & $\mathrm{X}_{\mathrm{ell} p}$ & \\
\hline 1 & $\mathbf{X}_{121}$ & $\mathbf{X}_{122}$ & $\ldots$ & $\mathbf{X}_{12_{\mathrm{p}}}$ & \multirow{6}{*}{ II } \\
\hline 2 & $\mathbf{X}_{2 n 1}$ & $\mathrm{X}_{212}$ & $\ldots$ & $\mathbf{x}_{\mathrm{np}_{\mathrm{p}}}$ & \\
\hline . & . & . & . & . & \\
\hline . & . & . & . & . & \\
\hline . & . & . & . & . & \\
\hline $\mathbf{n}_{2}$ & $\mathrm{X}_{\mathrm{a} 211}$ & $\mathrm{X}_{\mathrm{e} 212}$ & $\ldots$ & $\mathrm{X}_{\mathrm{an3p}}$ & \\
\hline . & . & . & . & . & \multirow{9}{*}{$\mathbf{m}$} \\
\hline . & . & . & . & . & \\
\hline . & . & . & . & . & \\
\hline 1 & $\mathbf{X}_{\text {lawl }}$ & $\mathbf{X}_{1 \mathrm{~m} 2}$ & $\ldots$ & $\mathrm{X}_{\text {lmg }}$ & \\
\hline 2 & $\mathbf{X}_{\text {lwal }}$ & $\mathbf{X}_{2 \mathrm{~ms}}$ & $\ldots$ & $\mathrm{X}_{\text {2m }}$ & \\
\hline . & . & . & . & . & \\
\hline . & . & . & . & . & \\
\hline . & . & . & . & . & \\
\hline $\mathbf{n}_{\mathbf{m}}$ & $\mathrm{X}_{\mathrm{amm}-1}$ & $\mathbf{X}_{\text {amm }}$ & $\ldots$ & $x_{\text {mann }}$ & \\
\hline
\end{tabular}

Source: Jaouni and Ghanem

The characteristic function was based on several variables (the number of infectious diseases in the Syrian governorates) which were collected from each governorate during the study years from 2001-2017. These groups derived from cluster analysis were used in the discriminatory analysis in the cases of two groups: 
1- The dependent variable representing the state of the governorate (1 represents the first cluster governorates with low number of communicable diseases, 2 represents the second cluster governorates with moderate number of communicable diseases, 3 represents the third cluster governorate with high number of communicable diseases).

2-The Independent variables were represented by groups of communicable diseases which were:

(flaccid paralysis, neonatal tetanus, meningitis, summer epidemic diarrhea, malaria, tuberculosis, measles, whooping cough, diphtheria, hepatitis, rubella, mumps, tetanus, cutaneous leishmaniasis, visceral leishmaniasis, schistosomiasis, brucellosis, typhoid fever, Dog, flu and acute diarrhea)

\subsection{Normal distribution test:}

The statistical test of the natural distribution didn't give us positive result but the group of the study consist of 21 diseases in 14 governorates during the study period from 2001-2017, and based on the law of large number we can consider that the variables of the study subject to the normal distribution [21]

\subsection{Homogenization condition:}

To determine the extent of data homogeneity for each of the independent variables, we used the (Box's M) and found that homogeneity condition of the variables was met.

Table (7): Test for Homogeneity of Contrast and Contrast

\begin{tabular}{rr|r}
$\begin{array}{r}\text { Average Linkage (Between } \\
\text { Groups) }\end{array}$ & Rank & Log Determinant \\
\hline Pooled within-groups & 11 & 89.454 \\
\hline
\end{tabular}

The ranks and natural logarithms of determinants printed are those of the group covariance matrices.

Source: prepared by researchers using Spss25

The Log Determinant value of the independent variable levels grouped into three groups, so that whenever the value of specified logarithm is larger than the matrix of that group differs from the rest and it shows 
clearly. Therefore, the second group (the second cluster where the average number of infections) where the most dependent variables have accumulated (s). The following table shows the value of Box's $M$ test for equality in covariance matrices, which shows the functions of discriminatory functions. The values of Log Determinants equal to all groups assumes that matrices are homogenous for common variations [22].

Table (8): Box's M

Average Linkage

$\log$

(Between Groups

Rank Determinant

\begin{tabular}{rrrr}
\hline 1 & $0^{* *}$ & .00 \\
\hline 2 & 2 & $-.332-$ \\
\hline 3 & 1 & $.614^{*}$ \\
\hline
\end{tabular}

Source: prepared by researchers using Spss25

Considering the difference of the groups through the differential functions and the value of Log Determinants in the three group and zero-hypothesis test for variance matrices are equal to basic discriminatory function. This indicates homogeneity and no differences, so two tables are treated jointly to test for homogeneity.

\subsection{Test for no self-correlation between independent variables:}

The correlation matrix between independent variables shows that selfcorrelation between most independent variables is weak and this increase the discriminatory ability of the variables.

\subsection{Test the significance of variables in discriminatory function:}

The mean of the variables in the groups were calculated as shown in the following table:

Table (9): Arithmetic averages numbers of infectious diseases for three groups

\begin{tabular}{|c|c|c|c|c|c|c|c|c|c|c|c|}
\hline & $x_{1}$ & $x_{2}$ & $x_{3}$ & $x_{4}$ & $x_{5}$ & $x_{6}$ & $x_{7}$ & $x_{8}$ & $x_{9}$ & $x_{10}$ & $x_{11}$ \\
\hline $\begin{array}{l}\text { First } \\
\text { group }\end{array}$ & 211 & 2 & 830 & 0 & 0 & 9099 & 551 & 62 & 0 & 4385 & 106 \\
\hline $\begin{array}{l}\text { Secon } \\
\text { d } \\
\text { group }\end{array}$ & 177.73 & $\begin{array}{r}7.4 \\
5\end{array}$ & 380.73 & 0 & $\begin{array}{r}7.1 \\
8\end{array}$ & $\begin{array}{r}1758.6 \\
4\end{array}$ & $\begin{array}{r}556.9 \\
1\end{array}$ & $\begin{array}{r}192.5 \\
5\end{array}$ & 0.09 & $\begin{array}{r}4322.6 \\
4\end{array}$ & $\begin{array}{r}59.6 \\
4\end{array}$ \\
\hline $\begin{array}{l}\text { Third } \\
\text { group }\end{array}$ & 296.5 & 4 & 473.5 & 0 & 0 & 6070 & 786 & 407.5 & 0 & 4919 & 28 \\
\hline & $x_{12}$ & $x_{13}$ & $\mathrm{x}_{14}$ & $\mathrm{x}_{15}$ & $x_{16}$ & $x_{17}$ & $\mathbf{x}_{18}$ & $\mathbf{x}_{19}$ & $\mathbf{x}_{20}$ & $\mathrm{x}_{21}$ & \\
\hline $\begin{array}{l}\text { First } \\
\text { group }\end{array}$ & 5236 & 0 & 12972 & 62 & 0 & 26836 & 881 & 2 & 32591 & 151472 & \\
\hline $\begin{array}{l}\text { Secon } \\
\text { d } \\
\text { group }\end{array}$ & $\begin{array}{r}2700.3 \\
6\end{array}$ & $\begin{array}{r}1.6 \\
4\end{array}$ & $\begin{array}{r}25375 . \\
73\end{array}$ & $\begin{array}{r}17.9 \\
1\end{array}$ & $\begin{array}{r}2.7 \\
3\end{array}$ & $\begin{array}{r}17480 . \\
36\end{array}$ & 3321 & 3.55 & $\begin{array}{r}210199 \\
.5\end{array}$ & $\begin{array}{r}122394 \\
.8\end{array}$ & \\
\hline $\begin{array}{l}\text { Third } \\
\text { group }\end{array}$ & 3370.5 & 6.5 & 151832 & 85 & 0 & $\begin{array}{r}19885 . \\
5\end{array}$ & $\begin{array}{r}5367 . \\
5\end{array}$ & 6.5 & 50343 & $\begin{array}{r}109937 \\
.5\end{array}$ & \\
\hline
\end{tabular}

Source: prepared by researchers using Spss25 
We note from the previous table that the highest value of the mean in the provinces for three groups was in the influenza group, where it reached 2010199.5 in the second group. The lowest means was in the diphtheria group where it was 0.09 in the second group too (excluding zero values). The $\mathrm{F}$ test for each variable in the linear function is shown as in the following table:

Table 10: $F$ test for each variable in the linear function.

\begin{tabular}{|c|c|c|c|c|c|}
\hline & Wilks' Lambda & $\mathrm{F}$ & df1 & df2 & Sig. \\
\hline Hepatitis & .997 & .031 & 1 & 12 & .863 \\
\hline Rubella & .898 & 1.365 & 1 & 12 & .025 \\
\hline Mumps & .995 & .062 & 1 & 12 & .807 \\
\hline $\begin{array}{r}\text { Tetanus } \\
\text { electrophoresis }\end{array}$ & .745 & 4.098 & 1 & 12 & .066 \\
\hline $\begin{array}{r}\text { Cutaneous } \\
\text { leishmamiasis }\end{array}$ & .395 & 18.391 & 1 & 12 & .001 \\
\hline $\begin{array}{r}\text { Visceral } \\
\text { leishmaniasis }\end{array}$ & .649 & 6.483 & 1 & 12 & .026 \\
\hline Schistosomiasis & .976 & .290 & 1 & 12 & .600 \\
\hline Brucellosis & .999 & .017 & 1 & 12 & .897 \\
\hline Typhoid fever & .891 & 1.472 & 1 & 12 & .248 \\
\hline Dog & .857 & 2.008 & 1 & 12 & .182 \\
\hline Flu & .941 & .753 & 1 & 12 & .040 \\
\hline Acute diarrhea & .997 & .035 & 1 & 12 & .005 \\
\hline Flaccid paralysis & .829 & 2.481 & 1 & 12 & .141 \\
\hline Neonatal tetanus & .991 & .114 & 1 & 12 & .742 \\
\hline Meningitis & .996 & .045 & 1 & 12 & .005 \\
\hline \multicolumn{6}{|l|}{$\begin{array}{r}\text { Summer epidemic } \\
\text { diarrhea }\end{array}$} \\
\hline Malaria & .986 & .169 & 1 & 12 & .008 \\
\hline Tuberculosis & .812 & 2.783 & 1 & 12 & .012 \\
\hline Measles & .961 & .486 & 1 & 12 & .499 \\
\hline Whooping cough & .897 & 1.382 & 1 & 12 & .263 \\
\hline Diphtheria & .987 & .156 & 1 & 12 & .007 \\
\hline
\end{tabular}

In order to the test the significance of all the variables to see the importance of each variable in the discriminatory function and the extent of the impact on the results using unilateral variation. The above table shows that the variables $x_{20}$ (influenza), $x_{21}$ (acute diarrhea) are 
significant and have significant effect in terms of differentiation between groups, followed by variables $x_{3}$ (meningitis), $x_{9}$ (diphtheria), $x_{5}$ (malaria), $x_{11}$ (rubella), $x_{6}$ (tuberculosis), $x_{15}$ (visceral leishmaniasis) and $x_{14}$ (cutaneous leishmaniasis) while the other variables have no significance effect.

The results of the significance test of the distinctive effect. The result of the significance test of the distinctive values and the strength of the legal relationship

(Legal discriminatory analysis) are shown in the following table:

\begin{tabular}{rr|r|r|r} 
& & & & \\
Function & & & & $\begin{array}{r}\text { Canonical } \\
\text { Correlation }\end{array}$ \\
\hline 1 & Eigenvalue & \% of Variance & Cumulative \% & .975 \\
\hline 2 & $19.605^{\mathrm{a}}$ & 81.5 & 81.5 & .904 \\
\hline \multicolumn{7}{c|}{ a. First 2 canonical discriminant functions were used in the analysis. } \\
\hline \multicolumn{7}{c}{ Source: prepared by researchers using Spss25 }
\end{tabular}

The value of the Eigenvalues of the first model /19.605/ which is greater than 1 , it indicates that the discriminatory function has a great ability to distinguish and explains $81.5 \%$ of the total value of the variance between the groups of the incidence of communicable diseases under study. The value of the Eigenvalues of the second model4.462 and explains the value of $18.5 \%$ of the total value of the variation between groups of the number of infectious diseases under study. As for the correlation coefficient, its value for the first model 0.975 and 0.904 which are high values for both models and thus are important discriminatory function, the percentages of change in the dependent variables were $97.5 \%$ and $90.4 \%$ in both models, the remaining of the variance were $2.5 \%$ and $9.6 \%$ that due to differences between groups. 
The Wilk's Lambda test value is shown in the table below:

Table (12): Wilks' Lambda

\begin{tabular}{rr|r|r|r} 
Test of Function(s) & Wilks' Lambda & Chi-square & df & Sig. \\
\hline 1 through 2 & .009 & 28.340 & 22 & .016 \\
\hline 2 & .183 & 10.186 & 10 & .042 \\
\hline
\end{tabular}

Source: prepared by researchers using Spss25

From the previous table, the two functions are significant and the value of $(x)$ for both function is small $(0.009,0.183)$ indicating the high discriminatory power of the two discriminatory functions, this means that the three groups (provinces with low, medium and high numbers of communicable diseases) differentiate among them based on dependent variables which makes us reject the second hypothesis.

The structural matrix expresses the type and structure of the correlation between the differentiation function and the variable entered in the differentiation function, the structural matrix is illustrated in the following table:

Table (13): Structure Matrix

\begin{tabular}{|c|c|c|c|c|c|c|c|c|c|c|c|}
\hline \multicolumn{2}{|c|}{$\begin{array}{l}\text { The variable entered } \\
\text { in the differentiation }\end{array}$} & $\begin{array}{c}\text { Visceral } \\
\text { leishmaniasis }\end{array}$ & $\begin{array}{l}\text { Cutaneous } \\
\text { leishmaniasis }\end{array}$ & Schistosomiasis & Flu & Meningitis & Mumps & Tuberculosis & $\begin{array}{l}\text { Tetanus } \\
\text { electrophoresis }\end{array}$ & $\begin{array}{l}\text { Neonatal } \\
\text { tetanus }\end{array}$ & Brucellosis \\
\hline \multirow{2}{*}{ Function } & 1 & *407. & *-316.- & *278. & *260. & *-085.- & *-066.- & -196.- & $-228 .-$ & $\begin{array}{c}026 \\
.-\end{array}$ & 029. \\
\hline & 2 & $-350 .-$ & 256. & 110. & $-133 .-$ & 057. & 056. & *382. & *339 & $\dot{*}_{-055}^{\cdot}$ & *221. \\
\hline \multicolumn{2}{|c|}{$\begin{array}{l}\text { The variable entered } \\
\text { in the differentiation }\end{array}$} & $\begin{array}{l}\text { Flaccid } \\
\text { paralysis }\end{array}$ & $\begin{array}{l}\text { Typhoid } \\
\text { fever }\end{array}$ & $\begin{array}{l}\text { Whooping } \\
\text { cough }\end{array}$ & $\begin{array}{c}\text { Acute } \\
\text { diarrhea }\end{array}$ & Rubella & Measles & Dog & Malaria & Hepatitis & Diphtheria \\
\hline \multirow{2}{*}{ Function } & 1 & $-007 .-$ & $-116 .-$ & 044. & $-059 .-$ & -083.- & 007. & -001 & 017.- & 001. & $\begin{array}{c}017 \\
.-\end{array}$ \\
\hline & 2 & *221. & *156. & *151. & *-150.- & *-144.- & *094. & *066. & *-062. & *024. & ${ }^{*}-060$ \\
\hline
\end{tabular}


The results of the previous table (13) can be explained by the following table:

Table (14): Interpretation of the results of the structural matrix table

The variables $x 13, x 14, x 15, x 16, x 17, x 18, x 19, x 20, x 21$ aren't including in the analysis

\begin{tabular}{|c|c|}
\hline \multicolumn{2}{|c|}{ Function } \\
\hline 1 & 2 \\
\hline $\begin{array}{l}\text { There is a positive correlation of } \\
2.6 \% \text { between the function and the } \\
\text { variable } x_{2}\end{array}$ & $\begin{array}{c}\text { There is a positive correlation of } \\
0.057 \% \text { between the function and the } \\
\text { variable } x_{3}\end{array}$ \\
\hline $\begin{array}{l}\text { There is a positive correlation of } \\
1.7 \% \text { between the function and the } \\
\text { variable } x_{5}\end{array}$ & $\begin{array}{l}\text { There is a positive correlation of } \\
0.056 \% \text { between the function and the } \\
\text { variable } x_{12}\end{array}$ \\
\hline $\begin{array}{l}\text { There is a positive correlation of } \\
4.4 \% \text { between the function and the } \\
\text { variable } x_{8}\end{array}$ & $\begin{array}{l}\text { There is a positive correlation of } \\
0.382 \% \text { between the function and the } \\
\text { variable } x_{6}\end{array}$ \\
\hline $\begin{array}{l}\text { There is a positive correlation of } \\
1.7 \% \text { between the function and the } \\
\text { variable } x_{9}\end{array}$ & $\begin{array}{l}\text { There is a positive correlation of } \\
0.221 \% \text { between the function and the } \\
\text { variable } x_{1}\end{array}$ \\
\hline $\begin{array}{l}\text { There is a positive correlation of } \\
0.01 \% \text { between the function and the } \\
\text { variable } x_{10}\end{array}$ & $\begin{array}{l}\text { There is a positive correlation of } \\
2.4 \% \text { between the function and the } \\
\text { variable } x_{10}\end{array}$ \\
\hline $\begin{array}{l}\text { There is a negative correlation of } \\
8.5 \% \text { between the function and the } \\
\text { variable } x_{3}\end{array}$ & $\begin{array}{l}\text { There is a positive correlation of } \\
0.151 \% \text { between the function and the } \\
\text { variable } x_{8}\end{array}$ \\
\hline $\begin{array}{l}\text { There is a negative correlation of } \\
6.6 \% \text { between the function and the } \\
\text { variable } x_{12}\end{array}$ & $\begin{array}{c}\text { There is a positive correlation of } \\
0.094 \% \text { between the function and the } \\
\text { variable } x_{7}\end{array}$ \\
\hline $\begin{array}{c}\text { There is a negative correlation of } \\
19.6 \% \text { between the function and the } \\
\text { variable } x_{6}\end{array}$ & $\begin{array}{l}\text { There is a negative correlation of } \\
0.144 \% \text { between the function and the } \\
\text { variable } x_{11}\end{array}$ \\
\hline $\begin{array}{l}\text { There is a negative correlation of } \\
0.07 \% \text { between the function and the } \\
\text { variable } x_{1}\end{array}$ & $\begin{array}{c}\text { There is a negative correlation of } \\
0.062 \% \text { between the function and the } \\
\text { variable } x_{5}\end{array}$ \\
\hline $\begin{array}{l}\text { There is a negative correlation of } \\
8.3 \% \text { between the function and the } \\
\text { variable } x_{11}\end{array}$ & $\begin{array}{c}\text { There is a negative correlation of } \\
0.060 \% \text { between the function and the } \\
\text { variable } x_{9}\end{array}$ \\
\hline $\begin{array}{l}\text { There is a negative correlation of } \\
0.07 \% \text { between the function and the } \\
\text { variable } x_{7}\end{array}$ & $\begin{array}{c}\text { There is a negative correlation of } \\
0.055 \% \text { between the function and the } \\
\text { variable } x_{2}\end{array}$ \\
\hline
\end{tabular}

Source: prepared by researchers using Spss25 
As for the coefficients standard characteristic function are as shown in the following table:

Table (15) : Standardized Canonical Discriminant Function Coefficients

\begin{tabular}{|r|l|l|r|l|l|l|l|l|l|l|l|l|}
\hline $\begin{array}{l}\text { Flacci } \\
\mathrm{d} \\
\text { paral } \\
\text { ysis }\end{array}$ & $\begin{array}{l}\text { Neon } \\
\text { atal } \\
\text { tetan } \\
\text { us }\end{array}$ & $\begin{array}{l}\text { Menin } \\
\text { gitis }\end{array}$ & $\begin{array}{l}\text { Mala } \\
\text { ria }\end{array}$ & $\begin{array}{l}\text { Tubercu } \\
\text { losis }\end{array}$ & $\begin{array}{l}\text { Meas } \\
\text { les }\end{array}$ & $\begin{array}{l}\text { Whoo } \\
\text { ping } \\
\text { cough }\end{array}$ & $\begin{array}{l}\text { Diphth } \\
\text { eria }\end{array}$ & $\begin{array}{l}\text { Hepa } \\
\text { titis }\end{array}$ & $\begin{array}{l}\text { Rub } \\
\text { ella }\end{array}$ & $\begin{array}{l}\text { Mu } \\
\text { mps }\end{array}$ & \\
\hline $\begin{array}{r}1.66 \\
6\end{array}$ & $-369-$ & $3.747-$ & $\begin{array}{r}2.44 \\
4-\end{array}$ & $-1.945-$ & $-053-$ & 3.236 & 4.845 & 2.008 & $\begin{array}{r}1.37 \\
4-\end{array}$ & $\begin{array}{r}.385 \\
-\end{array}$ & $\begin{array}{r}\text { Funct } \\
\text { ion }\end{array}$ \\
\hline$-766-$ & 0.283 & $-.647-$ & $\begin{array}{r}2.21 \\
5\end{array}$ & 1.858 & $\begin{array}{r}3.10 \\
6-\end{array}$ & $-.743-$ & 1.352 & 4.458 & $\begin{array}{r}5.93 \\
3-\end{array}$ & $\begin{array}{r}3.08 \\
3\end{array}$ & 2 & \\
\hline
\end{tabular}

Source: prepared by researchers using Spss25

From the preceding table which preceding table which expresses diphtheria $x 9$ the most important in the differentiation analysis function in the first model, while the variable $x 10$ that expresses hepatitis is the most important in the differentiation analysis function in the second model

- Classification function equations:

During the data of table 15 we concluded the classification of observations in the sample studies.

Table (16): Classification Function Coefficients

\begin{tabular}{ll|l|l} 
& 1 & 2 & 3 \\
\hline Flaccid paralysis & $-.022-$ & .238 & .203 \\
\hline $\begin{array}{l}\text { Neonatal } \\
\text { tetanus }\end{array}$ & $-.701-$ & $-1.189-$ & $-1.073-$ \\
\hline Meningitis & .205 & .036 & .021 \\
\hline Malaria & .874 & $-.937-$ & $-.428-$ \\
\hline Tuberculosis & .006 & $-.008-$ & $-.004-$ \\
\hline Measles & .026 & .031 & $-.006-$ \\
\hline Whooping cough & $-.127-$ & .065 & .054 \\
\hline Diphtheria & $-307.400-$ & $-56.531-$ & $-25.349-$ \\
\hline Hepatitis & $-.017-$ & $-.011-$ & $-.006-$ \\
\hline Rubella & 1.818 & 1.446 & .621 \\
\hline Mumps & $-.007-$ & $-.011-$ & $-.004-$ \\
\hline \begin{tabular}{l} 
(Constant) \\
\hline Fisher's linear discriminant functions
\end{tabular} Source: prepared by researchers using Spss25 \\
\hline
\end{tabular}

1- Classification function where the governorate has low incidence of communicable diseases (first group): 


$$
\begin{aligned}
& Z 1=-152.005-0.022 x_{1}-0.007 x_{2}+0.205 x_{3}+0.874 x_{5} \\
&+0.006 x_{6}+0.026 x_{7}-0.127 x_{8}-307.400 x_{9} \\
&-00.17 x_{10}+1.818 x_{11}-0.007 x_{12}
\end{aligned}
$$

2- Classification function where the governorate has moderate incidence of communicable diseases (second group):

$$
\begin{gathered}
Z 2=-30.541+0.238 x_{1}-1.189 x_{2}+0.036 x_{3}-0.937 x_{5} \\
-0.008 x_{6}+0.031 x_{7}+0.065 x_{8}-56.531 x_{9} \\
-0.011 x_{10}+1.446 x_{11}-0.011 x_{12}
\end{gathered}
$$

3- Classification function where the governorate has high incidence of communicable diseases (third group):

$$
\begin{gathered}
Z 3=-17.923+0.203 x_{1}-1.073 x_{2}+0.021 x_{3}-0.428 x_{5} \\
-0.004 x_{6} \pm 0.006 x_{7}+0.054 x_{8}-25.349 x_{9} \\
-0.006 x_{10}+0.621 x_{11}-0.004 x_{12}
\end{gathered}
$$

\begin{tabular}{|c|c|c|c|c|c|c|}
\hline & & Average Linkage & Pre & Group & Jership & \multirow[b]{2}{*}{ Total } \\
\hline & & (Between Groups) & 1 & 2 & 3 & \\
\hline \multirow[t]{6}{*}{ Original } & Count & 1 & 0 & 0 & 1 & 1 \\
\hline & & 2 & 0 & 6 & 5 & 11 \\
\hline & & 3 & 0 & 0 & 2 & 2 \\
\hline & $\%$ & 1 & .0 & .0 & 100.0 & 100.0 \\
\hline & & 2 & .0 & 54.5 & 45.5 & 100.0 \\
\hline & & 3 & .0 & .0 & 100.0 & 100.0 \\
\hline
\end{tabular}

Based on the results of the previous three equations, we calculate the discriminatory score for each of the observations in the studied sample and make the decision for the group which this particular view belongs by determining the highest discriminatory score.

\subsection{Classification Result:}

The table shows that results of the classification where the elements of the main country of the table for the cases classified correctly. One of the provinces with low infection number is one where they are all rated $100 \%$ as is the case in medium infection number of all province where they are rated $100 \%$. The same thing in the provinces with high infection number are two where they are rated $100 \%$. 


\subsection{Calculation of centers of group centroids:}

After the classification process we have three sub-groups and each group has a centroid. The following table shows functions at group centroids in discriminatory analysis of three sub-group.

Table (18): Functions at Group Centroids

\begin{tabular}{rr|r}
$\begin{array}{c}\text { Average Linkage } \\
\text { (Between Groups) }\end{array}$ & 1 & 2 \\
\hline 1 & $-14.144-$ & .208 \\
\hline 2 & 1.035 & $-.844-$ \\
\hline 3 & 1.382 & 4.539 \\
\hline Source: prepared by researchers using Spss25
\end{tabular}

The values in the previous table express the functions of group concentration. These values are located in different directions and determine the distance between each of the two values as a whole (21). Depending on the Spss 25 program to calculate the distance mentioned, the following figure shows the distribution of infectious diseases in the Syrian governorates during the study years according to the two discriminator analysis function where the first discrimination function is the horizontal axis and the second discrimination function is the vertical axis.

Figure (3): The distribution of infectious diseases in the Syrian governorates during the years of study according to the functions of discrimination at the group centers.

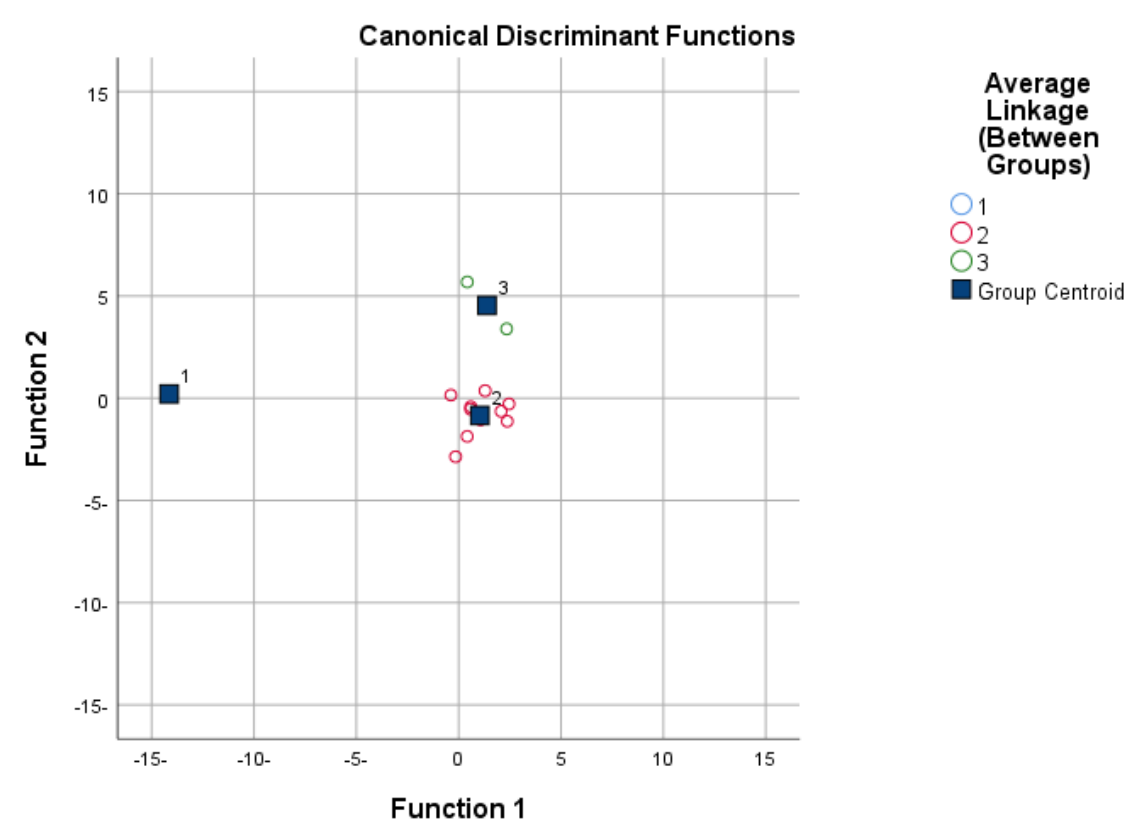




\section{Conclusions:}

The number of infectious diseases in the Syrian governorates showed no homogeneity during the years of research to be distributed among three clusters ( the first cluster with low injuries numbers, the second cluster with moderate injuries numbers, and the third cluster with high injuries numbers) . The results of the use of cluster analysis have been characterized by a comprehensive linking method that the second cluster with medium number of injuries has been collected by the largest number of Syrian governorates where it reached 11 governorates and this is in line with the average levels of infectious diseases, due to the high level of health care and awareness in people. Although the years of study include the period of unrest in Syria and the declined of the state of health services in some provinces with security and health situation. The results of the analysis show that the group of special numbers of diphtheria is the most important in the differentiation analysis function in the first model, while the group of numbers for hepatitis is the most important in the function of analysis of differentiation in the second model. Thus, the three groups (low, moderate and high injuries) differentiation among them based on the variables included in the analysis according to two major distinctions, confirming that the fourteen Syrian governorates have been correctly classified according to each group which they belong.

\section{Acknowledgment:}

The authors thank the doctors who are working in the Director of Communicable Diseases in the Syrian Ministry of Health for their assistance in providing the data, Dr. Hazem Abdo, Dr. Rania Hassan of Tartous University in Syria and Engineer Ahmad Moharm in Egypt in preparing the research. 


\section{References:}

[1] B. Markoski و T. Melovska ،"Geographical distribution of diseases in the world تأليف "، the 5th Congress of the Ecologists of Macedonia, with international participation (Ohrid, 19th-22nd October 2016) Special issues of the Macedonian Ecological Society ، Macedonia .2016 ،

[2] Centers for Disease Control and Prevention (CDC) 'Principles of Epidemiology in Public Health Practice An Introduction to Applied Epidemiology and Biostatistics المجلا Third Edition ،Atlanta: U.S. DEPARTMENT OF HEALTH AND HUMAN SERVICES ‘2011 ‘p. 52.

[3] F. El Allaki ‘. M. Bigras-Poulin ،P. Michel . و A. Ravel ،"A Population Health Surveillance Theory "'Epidemiology and Health رق و 2012.

[4] A. Dalvi و J. Braga" ، Spatial diffusion of the 2015-2016 Zika, dengue and chikungunya epidemics in Rio de Janeiro Municipality, Brazil "،Epidemiology and Infection رقم ، e237, 1-13 ‘pp. 2-9 .2019 ،

[5] H. Ziadi and h. Hussein, "Spatial Variability of Communicable Diseases in the Souq AlShuyoukh District for the Period 2004-2010," Thi-Qar University Journal, No. 2, pp. 7993, March 2013.

[6] . M. Melina, B. Gelfeld, A. Okunogbe and C. Paul, Identifying Future Areas Most Vulnerable to Infectious Disease Exposure Index, Santa Monica, CA: NATIONAL DEFENSE RESEARCH INSTITUTE, 2016, p. 9.

[7] G. Shannan ' "Communicable diseases in the Mediterranean region "'The journal of the international federation of clinical chemistry and laboratory medicine ‘p. 1567 . Novmber 2018.

[8] J. AMELI 'Communicable Diseases and Outbreak Control 'Department of Emergency Medicine, The Warren Alpert Medical School of Brown University .2015 ،

[9] F. Faruque ،A. Bhuiyan ،M. Kanu . و B. Brackin ،Infections And Communicable Diseases Mississppi ‘Mississppi ‘2018 ‘pp. 2-3.

[10] L. Nguyen 'Health Implications of INFECTIOUS DISEASES DUE TO CLIMATE CHANGE A CASE STUDY OF HO CHI MINH CITY 'Thesis presented in part-fulfilment of the degree of Master of Science in accordance ‘2010 ‘p. 5.

[11] "World Health Organization - Regional Office for the Eastern Mediterranean," 2005. [Related]. Available: http://www.emro.who.int/en/health-topics/infectiousdiseases/index.html. [Date of arrival 1810 2019].

[12] J. A. Patz ،A. K. Githeko ‘. J. P. McCarty ،S. Hussein ،U. Confalonieri و N. de Wet ، "Climate change and infectious diseases .2010 "،

[13] Y.-C. Lo ،"Implementation of the IHR Joint External Evaluation: Taiwan's Experiences "، 
Health Security رقم، Number 2 ‘p. 132 .2017،

[14] WHO-Regional Office for the Eastern Mediterranean, 2012. [Connected]. Available: http://www.emro.who.int/en/annual-report/2012/communicable-diseases.html. [Date of arrival 610 2019].

[15] R. Raslan ،s. El sayegh ،s. Chams ‘n. Chams ،a. Lone $\mathbf{i}$ i. Hussein ،"RaslanRe-Emerging VaccinePreventable Diseases in "‘Front. Public Health, number5, p: 1-7 .2017 ،

[16] Syrian Ministry of Health, 2014. [Connected]. Available: http://www.moh.gov.sy/Default.aspx?tabid=453\&language=en-YE. [Date of arrival 6 10 2019].

[17] World Health Organization ‘COMMUNICABLE DISEASE PROFILE ‘geneva ‘2001 ‘p. 2.

[18] World Health Organization, WHO's work in the Eastern Mediterranean Region, Annual Report of the Regional Director, Cairo: World Health Organization, 2017, pp. 29-31.

[19] N. Mustafa, "The Use of Some Methods of Cluster Analysis in Classification with the Application of Action +," Technical Journal, Volume 20, No. 2, pp. 2-4, 2007.

[20] A. Ghanem and F. Al-Jaouni, "Multivariate Statistical Analysis (Discriminatory Analysis): Structure in the Characterization and Distribution of Households within the Socio-Economic Society," Damascus University Journal of Economic and Legal Sciences, Vol. 2, p. 316, 2007.

[21] I. Ali and Y. Alloush, Strategic Planning for Small Projects and Their Role in Economic and Social Development in Syria, Lattakia: Tishreen University, 2018, p. 124.

[22] M. Al-Bayati, Analysis of Statistical Data Using SPSS Statistical Program, Amman: Dar Al-Hamed, 2005.

[23] y.-. c. Lo '"Implementation of the IHR Joint External Evaluation: Taiwan 's experirences "،Health Security number 2 ‘p. 132.2017 ،

[24] J. AMELI ‘"Communicable Diseases and Outbreak Control "‘Emergency Medicine Association of Turkey 'p. 21.

[25] A. Al Zayed, LLC Physics, p. Type, p. Night, a. Kandil, M. Bo Talib and F. Al-Manawer, "Problems of Social Policy in Risk Management in GCC Countries," Social Studies Series, p. 10, 2013. 